УДК 347.440 .51

DOI https://doi.org/10.32849/2663-5313/2020.2.08

Наталія Люльчук,

аспірант кафедри чивільного права і прочесу

Національної академії внутрішніх справ

\title{
ОСОБЛИВОСТІ УКЛАДЕННЯ ДОГОВОРУ ПРО НАДАННЯ ПРАВНИЧОЇ ДОПОМОГИ
}

Стаття присвячена дослідженню особливостей укладання договору про надання правничої допомоги. Укладаючи договір, сторони підпорядковують себе чинному правовому порядку, частиною якого є правила про дійсність угод і правила про укладення договору, з дотриманням приниипу свободи договору, яка забезпечується низкою правових приписів: суб'єкти иивільного права вільні у вирішенні питання, чи варто їм укладати договір; під час укладення договору сторони є вільними у виборі контрагента; сторони є вільними у виборі виду договору; сторони є вільними у визначенні умов договору. Договір про надання правничої допомоги за своєю правовою природою є договором оплатного надання послуг, якому притаманні окремі елементи представниитва. Цей договір є каузальним, оплатним, консенсуальним, фідуиіарним та двостороннє-зобов'язувальним, а також має ознаки публічності і $у$ певних випадках може розглядатися як споживчий. Наведені ознаки відповідним чином характеризують і особливості укладання договору про надання правничої допомоги за иивільним законодавством України. За загальним правилом договір набуває чинності і стає обов'язковим для сторін з моменту його укладення. Особливість договору на надання правничої допомоги полягає в тому, що, з одного боку, він не є публічним, але з іншого - пропозиція з боку правників може містити елементи публічної оферти. Крім випадків, зазначених у Законі України «Про адвокатуру і адвокатську діяльність», неможливості прийняття доручення на ведення справи, які законодавеиь розглядає як форми прояву конфлікту інтересів, адвокат не має права відмовитися від укладення договору з будь-ким, хто б не звернувся до нвого. Втім, згадані положення в обов'язковому порядку на решту правників не поширюються, тому повною мірою діє принии свободи договору. Водночас в умовах високої вірогідності скасування найближчим часом адвокатської монополії на судове представництво умови та порядок укладання договору про надання правничої допомоги мають бути уніфіковані незалежно від спеиифіки статусу професійного правника, який виступає стороною такого договору.

Ключові слова: адвокат, оферта, акцепт, особа, адвокатська монополія.

Постановка проблеми. Укладаючи договір, сторони підпорядковують себе чинному правовому порядку, частиною якого є правила про дійсність угод і правила про укладення договору, з дотриманням принципу свободи договору, яка забезпечується низкою правових приписів: суб'єкти цивільного права вільні у вирішенні питання, чи варто їм укладати договір; під час укладення договору сторони є вільними у виборі контрагента; сторони є вільними у виборі виду договору; сторони є вільними у визначенні умов договору. Договір про надання правничої допомоги за своєю правовою природою $€$ договором оплатного надання послуг, якому притаманні окремі елементи представництва. Цей договір є каузальним, оплатним, консенсуальним, фідуціарним та двостороннезобов'язувальним, а також має ознаки публічності і у певних випадках може розглядатися як споживчий. Наведені ознаки відповідним чином характеризують і особливості укладання договору про надання правничої допомоги за цивільним законодавством України.
Стан дослідження. Дослідженню питань цивільно-правового регулювання надання правничої допомоги приділялася увага у наукових працях С. Борисенка Є. Васьковського, I. Гловацького, А. Джуської, В. Заборовського, В. Личко, М. Кратенка, П. Павліша, В. Попелюшка, О. Святоцького, I. Синяка, А. Титова, I. Токмакова, В. Третьякової, О. Філонова, В. Шкарупи та інших дослідників. Водночас питання специфіки договору про надання правничої допомоги лишається актуальним як у практичному, так і в теоретичному аспекті.

Мета статті полягає у дослідженні особливостей укладання договору про надання правничої допомоги.

Виклад основного матеріалу. Загальний порядок укладення договору визначається главою 53 ЦК України [1] і передбачає наявність двох етапів (стадій) у процесі укладення договору: пропозиція однієї сторони, звернена до іншої, вступити в договірні відносини (оферта) та прийняття пропозиції 
іншою стороною (акцепт). За загальним правилом договір визнається укладеним 3 моменту одержання особою, яка направила пропозицію укласти договір, відповіді про прийняття цієї пропозиції (тобто акцепту оферти [2]).

Під офертою розуміється пропозиція укласти договір, проте не всяка пропозиція укласти договір набуває чинності оферти. Така пропозиція має відповідати таким обов'язковим вимогам: має бути адресована конкретній особі (особам); має бути досить виразною і виражати намір особи, яка її зробила, вважати себе зобов'язаною у разі iii акцепту; має містити всі істотні умови договору. За формою оферта може бути будь-якою: лист, телеграма, факс, е-мейл тощо. Крім того, офертою може виступати також і розроблений стороною, що пропонує укласти договір, проєкт такого договору. 3 моменту отримання оферти адресатом особа, що направила оферту, має співвідносити свої дії з можливими юридичними наслідками, які можуть бути викликані акцептом оферти. При цьому відповідно до ч. 3 ст. 641 ЦК України [1] оферта може бути відкликана до моменту або в момент іiї одержання адресатом. Оферта, одержана адресатом, не може бути відкликана протягом строку для відповіді, якщо інше не вказане у пропозиції або не випливає з ії̈ суті чи обставин, за яких вона була зроблена. Слід зазначити, що реклама й інші пропозиції, адресовані невизначеному колу осіб, які не є офертою і розглядаються як запрошення робити оферти, якщо інше не вказано у рекламі або інших пропозиціях (ч. 2 ст. 641 ЦК України [1]).

Акцептом визнається відповідь особи, якій адресована оферта, про її прийняття. Згідно зі ст. 642 ЦК України [1], акцепт має бути повним і безумовним. За загальним правилом мовчання не $\epsilon$ акцептом, якщо інше не випливає із закону, звичаїв ділового обігу або з попередніх ділових відносин сторін. Відповідь про згоду укласти договір на інших умовах, ніж запропоновано в оферті, не є акцептом, але водночас визнається новою офертою. Так само новою офертою визнається відповідь на пропозицію укласти договір, одержана із запізненням (ч. 2 ст. 645 ЦК України) [1].

Проаналізувавши основні положення, що визначають порядок укладення договору, слід зупинитися на особливостях цього питання у контексті укладення договору на надання правничої допомоги. На практиці найчастіше укладення такого договору відбувається шляхом досягнення згоди 3 усіх його істотних умов у разі безпосереднього звернення клієнта до конкретного правника, юридичної фірми, адвокатського об'єднання тощо. Клієнт в усній формі викладає свою пропозицію і може відразу ж окреслити коло своїх фінансових можливостей щодо оплати наданих у майбутньому правничих послуг. Це особливо характерно для процесу укладання договору про надання правничої допомоги, яка передбачає судове представництво, адже до адвокатів насамперед звертаються фізичні особи, які не володіють спеціальними знаннями у сфері права, тому не переймаються тим, аби скласти оферту $з$ дотриманням формальних вимог. Своєю чергою правник акцептує цю пропозицію або адресує потенційному клієнтові свою оферту. Найчастіше на практиці це відбувається в усній формі.

Договір про надання правничої допомоги за своєю природою не є публічним договором, але містить деякі ознаки публічного. Наприклад, відповідно до ч. 2 ст. 21 Закону України «Про адвокатуру та адвокатську діяльність» адвокату заборонено відмовлятися від надання правової допомоги, крім випадків, установлених законом [3]. Тож адвокат має право укласти договір з будьякими особами, які до нього звернуться, будучи пов'язаним своєю офертою 3 іншою особою, що, своєю чергою, підкріплюється і принципом неможливості відмови від прийнятого на себе зобов'язання з надання правничої допомоги, що є стабілізаційним складником цього договору [4, с. 108].

$\mathrm{y}$ сучасних умовах істотне значення в процесі виникнення договірних відносин 3 надання правничої допомоги відіграє реклама та інші пропозиції, адресовані невизначеному колу осіб. Публікації та повідомлення в засобах масової інформації, телевізійна реклама, вивіски, інтернет-сайти, на яких розміщені прайс-листи, що містять список найменувань правничих послуг та їх вартість, - усе це свідчить про активне рекламування правниками своєї діяльності. Досить результативною $є$ і так звана непряма реклама - консультація правника 3 конкретного питання, участь у дискусії, розповідь про успішно завершені судові справи тощо. Незважаючи на те, що подібного роду пропозиції, як зазначалося вище, не є офертою, вони є невід'ємною частиною процесу залучення клієнтів у сферу користування правничими послугами [4, с. 110].

Водночас пропозиція, яка містить всі істотні умови договору, з якої вбачається воля особи, що робить пропозицію, укласти договір на зазначених у пропозиції умовах 3 кожним, хто відгукнеться, визнається офертою (публічна оферта). Тож такою офертою 
можна вважати вивішувані в юридичних фірмах списки юридичних послуг з розмірами їх оплати за кожним видом послуг, особливо, коли йдеться про такі послуги, як надання клієнтові консультації з правових питань безпосередньо під час відвідування відповідної юридичної фірми чи офісу правника. При цьому, якщо йдеться про надання правничих послуг адвокатом, виходячи з природи договору, а також зазначених у законі про адвокатуру випадків неможливості прийняття доручення на ведення справи, адвокат не може надавати перевагу одній особі перед іншою щодо укладення такого договору, що також підтверджується соціальною значущістю і публічно-правовим характером діяльності адвоката.

Після узгодження принципових моментів сторони мають перейти до документального оформлення договору про надання правничої допомоги.

Під час укладання договору про надання правничої допомоги велике значення має визначення моменту виникнення договірного зв'язку. Факт наявності договірного зв'язку важливий не власне як такий, а внаслідок того, що він породжує ті правові наслідки, на які мають право розраховувати сторони договору. Натепер фактичний порядок оформлення відносин щодо надання правничої допомоги адвокатами та їх об'єднаннями, а також іншими правниками, юридичними фірмами тощо не завжди збігається: в одних випадках укладається договір від імені фірми, в інших випадках стороною по ньому виступає або адвокатське об'єднання, або юридична особа, напрямом діяльності якої $€$ надання правничих послуг, або безпосередньо правник (адвокат). Зокрема, досить часто в адвокатських конторах єдиним письмовим свідченням виникнення договірних зобов'язань стають або запис у реєстраційних документах колегії, або виданий адвокату ордер. Таке становище не сприяє встановленню стабільного договірного зв'язку та захисту інтересів сторін, втім певною мірою зумовлене положеннями ст. 26 Закону України «Про адвокатуру і адвокатську діяльність». Відповідно до зазначеної статті адвокатська діяльність здійснюється на підставі договору про надання правової допомоги, причому документами, що посвідчують повноваження адвоката на надання правової допомоги, можуть бути: «1) договір про надання правової допомоги; 2) довіреність; 3) ордер; 4) доручення органу (установи), уповноваженого законом на надання безоплатної правової допомоги» [3]. Отже, з одного боку, йдеться про обов'язкове укладання договору про надання правничої допо- моги, який можна оформити у різний спосіб: ордером, довіреністю, у формі письмового договору тощо, а з іншого боку - договір про надання правничої допомоги розглядається як альтернатива ордеру, довіреності та доручення. Тому вважаємо за доцільне внести до ст. 26 Закону України «Про адвокатуру і адвокатську діяльність» та до ст. 27 цього ж Закону зміни, які передбачатимуть, що довіреність, ордер, доручення тощо є документами, що посвідчують укладання договору про надання правової допомоги, який за загальним правилом укладається в письмовій формі. Такі зміни, на нашу думку, слугуватимуть повному усвідомленню сторонами договору про надання правничої допомоги своїх прав та обов'язків, а також належному виконанню вказаного договору загалом, адже тільки в договорі, що укладається в письмовій формі, можуть бути чітко відображені його предмет, права та обов'язки сторін, розмір і характер відповідальності тощо. Зауважимо, що відповідні положення щодо підстав для надання правничої допомоги і форми відповідного договору мають поширюватись не лише на адвокатську діяльність, але й на сферу надання правничих послуг загалом.

Виходячи з положень ч. 1, ч. 3 ст. 27 Закону України «Про адвокатуру i адвокатську діяльність» [3], договір про надання правничої допомоги - це цивільно-правовий договір, що укладається в простій письмовій формі між клієнтом і адвокатом (адвокатами) на надання юридичної допомоги самому клієнту або визначеній ним особі. Виходячи з цього, проста письмова форма є обов'язковою для угоди про надання правової допомоги, недотримання якої відповідно до ст. 218 ЦК України [1] не тягне за собою недійсність договору, адже про це безпосередньо не зазначено в законі. Натомість недотримання письмової форми договору позбавляє сторони права в разі спору посилатися на підтвердження угоди та їі умов на показання свідків, але не позбавляє їх права наводити письмові та інші докази. Ч. 2 ст. 218 також передбачає, що, якщо правочин, для якого законом встановлена його недійсність у разі недодержання вимоги щодо письмової форми, укладений усно і одна зі сторін вчинила дію, а друга сторона підтвердила їі вчинення, зокрема шляхом прийняття виконання, такий правочин у разі спору може бути визнаний судом дійсним. Це, однак, не стосується випадків, передбачених ч. 2 ст. 27 Закону України «Про адвокатуру і адвокатську діяльність» [3], за яких договір про надання правничої допомоги може бути укладений в усній формі. Як уже зазначалося у попередньому розділі цього дослідження, це випадки, коли клієнт 
невідкладно потребує надання правничої допомоги, а укладення письмового договору за конкретних обставин $є$ неможливим (за таких умов раціональним $є$ встановлення для сторін обов'язку щодо наступного письмового оформлення договору у найближчий можливий строк, причому до моменту такого оформлення підтвердженням факту укладання договору має слугувати поведінка сторін, яка засвідчує їхню волю до настання відповідних правових наслідків, у тому числі й мовчазна згода). Слід зауважити, що під час укладання такого договору в усній формі дещо ускладненим є момент визначення моменту виникнення взаємних прав та обов'язків сторін. Укладення договору в письмовій формі слугує запорукою для визначеності прав і обов'язків, стійкості відносин, гарантування відповідальності сторін за договором, у чому зацікавлений цивільний оборот, тому факт наявності договірних відносин визначити неважко, для визнання усної угоди такою, що тягне за собою встановлення (припинення, зміну) прав і обов'язків, необхідна наявність чітко висловленої волі сторін договору. Якщо розуміти під волею детерміноване і мотивоване бажання досягти поставленої мети, то для укладення договору необхідне узгодження бажань задля досягнення певної мети, тобто необхідно висловлення з узгодженої волі сторін, яке може здійснитися за допомогою дій [5, с. 24]. Фактично цими діями і формуються умови договору, адже шляхом його укладання здійснюється індивідуалізація цивільно-правової норми задля досягнення очікуваної сторонами договору мети [6, с. 25].

Таким чином, є підстави вважати, що для встановлення факту існування юридично зобов'язуючого договірного зв'язку 3 надання правничих послуг законодавча формула «досягнення згоди з усіх істотних умов договору» має наповнюватися специфічним змістом: про наявність такого договору буде свідчити письмова угода, а в разі його відсутності - усна, так само, як і дії, що встановлюють права і обов'язки і свідчать про збіг волевиявлення сторін щодо предмета зобов'язання, що визначається, наприклад, 3 таких обставин, як листування, перемовини, практика відносин сторін, їх поведінка, заяви тощо. Тобто йдеться про тлумачення договорів, факт існування яких ставиться під сумнів, про з'ясування дійсної спільної волі сторін з урахуванням мети договору за правилами, що застосовуються для тлумачення договору, коли буквальне значення тієї чи іншої умови неможливо з'ясувати шляхом зіставлення його з іншими умовами і змістом договору загалом [7, с. 13].

\section{Висновки}

За загальним правилом договір набуває чинності і стає обов'язковим для сторін з моменту його укладення. Особливість договору на надання правничої допомоги полягає в тому, що, з одного боку, він не є публічним, але 3 іншого - пропозиція з боку правників може містити елементи публічної оферти. Крім зазначених у Законі України «Про адвокатуру і адвокатську діяльність» [3] випадків неможливості прийняття доручення на ведення справи (ст. 28 Закону), які законодавець розглядає як форми прояву конфлікту інтересів, адвокат не має права відмовитися від укладення договору з будьким, хто б не звернувся до нього. Отже, згадані положення в обов'язковому порядку на решту правників не поширюються, тому повною мірою діє принцип свободи договору. Водночас 03 вересня 2019 року до Верховної Ради України внесено законопроєкт № 1013, яким передбачається скасувати адвокатську монополію шляхом внесення змін до статті 131-2 чинної Конституції України, згідно з якою виключно адвокат здійснює представництво іншої особи в суді (законопроєкт № 1013 передбачає залишити монополію тільки для захисту від кримінального обвинувачення) [8]. Нині цей законопроєкт отримав позитивний висновок Конституційного Суду [9] і може бути прийнятий у разі повторної підтримки конституційною більшістю парламенту (тобто більше 300 народних депутатів). Тож, на нашу думку, в умовах високої вірогідності скасування найближчим часом адвокатської монополії на судове представництво [10] умови та порядок укладання договору про надання правничої допомоги мають бути уніфіковані незалежно від специфіки статусу професійного правника, який виступає стороною такого договору.

\section{Список використаних джерел:}

1. Цивільний кодекс України. URL: https://zakon.rada.gov.ua/laws/show/435-15 (дата звернення: 10.12.2019).

2. Гражданское право : учебник : В 3 т. Т. 1. 6-изд., перераб. и доп. / Н.Д. Егоров, И.В. Елисеев и др. ; Отв. ред. А.П. Сергеев, Ю.К. Толстой. Москва : ТК Велби Изд-во «Проспект», 2004. С. 602.

3. Про адвокатуру та адвокатську діяльність : Закон України від 05.07.2012 p. URL: https://zakon.rada.gov.ua/laws/show/5076-17 (дата звернення: 10.12.2019).

4. Владимирова И.А. Особенности гражданскоправового регулирования оказания услуг адвокатом : дисс. ... канд. юрид. наук. Тверь, 2006. 202 с.

5. Ойгензихт В.А. Воля и волеизъявление: Очерки теории, философии и психологии права. Душанбе, 1983. С. 24. 
6. Вахнин И.Г. Учёт целей договора и целей деятельности сторон при формировании условий договора поставки. Законодательство. 2000. № 1. С. 25.

7. Щуковская О.М. Правовое регулирование деятельности по оказанию правовых услуг : автореф. дисс. ... канд. юрид. наук. Санкт-Петербург, 2001. $20 \mathrm{c}$.

8. Законопроєкт про внесення змін до Конституції України (щодо скасування адвокатської монополії) (реєстр. № 1013). URL: https://w1.c1.rada.gov.ua/pls/zweb2/webproc4 1?pf3511=66242 (дата звернення: 10.12.2019).
9. КСУ надав Висновок у справі щодо скасування адвокатської монополії. URL: http://www.ccu.gov.ua/novyna/ksu-nadavvysnovok-u-spravi-shchodo-skasuvannyaadvokatskoyi-monopoliyi (дата звернення: 28.12.2019)

10. Законопроєкт про скасування адвокатської монополії: чого чекати у разі прийняття. URL: https://ldn.org.ua/consultations/zakonoproektpro-skasuvannya-advokatskoji-monopoliji-chohochekaty-u-razi-pryjnyattya/ (дата звернення: 28.12.2019).

The article is devoted to the study of the peculiarities of concluding a legal aid agreement. In concluding a contract, the parties submit themselves to the applicable legal order, part of which is the rules on the validity of the agreements and the rules on the conclusion of the contract, with observance of the principle of freedom of contract, which is ensured by a number of legal requirements: the subjects of civil law are free to decide whether they should conclude the contract; the parties are free to choose the counterparty; the parties are free to choose the type of contract; the parties are free to determine the terms of the contract. A legal aid contract is, by its legal nature, a contract for the payment of services, which has particular elements of representation. This agreement is causal, remunerative, consensual, fiduciary, and bilaterally binding, and is public and may in some cases be considered consumer. The above features also characterize the peculiarities of concluding a legal aid agreement under the civil law of Ukraine. As a general rule, the contract enters into force and becomes binding on the parties from the moment of its conclusion. The peculiarity of a legal aid contract is that, on the one hand, it is not public, but on the other, a proposal by legal practitioners may contain elements of a public offer. Also, except in cases specified in the Law of Ukraine "On Advocacy and Attorney Activity" of impossibility of taking a power of attorney, which the legislator views as a form of conflict of interest, a lawyer has no right to refuse to conclude a contract with anyone who does not turn to him. However, the aforementioned provisions do not necessarily apply to the rest of the legal profession and therefore the principle of freedom of contract is fully applicable. At the same time, in the conditions of high probability of cancellation of a lawyer's monopoly on judicial representation in the near future, the terms and procedure for concluding a legal aid contract should be standardized regardless of the specific status of the professional lawyer who is a party to such contract.

Key words: lawyer, offer, acceptance, person, lawyer's monopoly. 